\title{
A CONTRIbUiÇÃO da dANÇA do VENTRE NA EDUCAÇÃO CORPORAL, SAÚDE FÍSICA E MENTAL, DE MULHERES QUE FREQUENTAM UM CENTRO DE ATENÇÃO PSICOSSOCIAL.
}

\section{RESUMO}

Diversas modalidades terapêuticas não tradicionais, como Ginástica, Yoga e Tai Chi Chuan, oferecem contribuições importantes na assistência a portadores de transtornos mentais em Centros de Atenção Psicossocial (CAPS), e, a Dança do Ventre, com suas características, reúne condições de oferecer a mesma contribuição, particularmente, às mulheres usuárias destes Centros. Assim sendo, o presente estudo teve por objetivo verificar a contribuição desta Dança na educação corporal, saúde física e mental das citadas mulheres. Para isto, planejamos 11 aulas de Dança do Ventre e aplicamos semanalmente a 9 mulheres usuárias de um CAPS, com diferentes diagnósticos, que se constituiram nos sujeitos do estudo, e, através de seus depoimentos, obtidos com questionários que aplicamos antes delas terem contato com as aulas; após vivenciarem toda a experiência, e, também, através de seus depoimentos, registrados ao final de cada aula por dois observadores participantes, treinados para esse fim, pudemos verificar a citada contribuição. Os resultados mostraram que, a Dança do Ventre, contribuiu na melhora da auto-estima e da auto-confiança das mulheres, auxiliou no seu tratamento no CAPS e teve contribuição considerável na educação corporal, na saúde física e mental delas, melhorando assim sua qualidade de vida, e, consequentemente, proporcionando um covívio melhor em seu meio social e familiar.

Palavras chave: dança do ventre, saúde, educação. 
CONTRIBUTION OF BELLY DANCING TO BODY EDUCATION, PHYSICAL AND MENTAL HEALTH OF WOMEN WHO ATTEND A PSYCHOSOCIAL CARE CENTER

\begin{abstract}
Various non-traditional therapeutic modalities, such as Gymnastics, Yoga and Tai Chi Chuan, offer important contributions to care for patients with mental disorders at Psychosocial Care Centers (PCC). The characteristics of Belly Dancing possess the necessary conditions to offer the same contribution, particularly to the women who use these Centers. This study aimed to verify the contribution of this dance type to the body education, physical and mental health of the above mentioned women. Hence, we planned 11 Belly Dancing classes, offered on a weekly basis to 9 women who attended a PCC, with different diagnoses, who were the subjects of this study. Their testimonies obtained by means of questionnaires, which were applied before they had any contact with the classes and after the entire experience, as well as their testimonies recorded at the end of each class by two participating observers, who had been trained for this purpose, allowed us to verify the above mentioned contribution. Results showed that Belly Dancing contributed to better self-esteem and self-confidence among these women, it helped in their treatment at the PCC and made a considerable contribution to their body education, physical and mental health, thus improving their quality of life and, consequently, enabling them to live in their social and family environment.
\end{abstract}

Keywords: belly dancing, health, education. 


\section{CONTRIBUCIÓN DE LA DANZA DE VIENTRE EN LA EDUCACIÓN CORPORAL, SALUD FÍSICA Y MENTAL, DE MUJERES QUE FRECUENTAN UN CENTRO DE ATENCIÓN PSICOSOCIAL.}

\section{RESUMEN}

Diversas modalidades terapéuticas no tradicionales, como Gimnásia, Yoga y Tai Chi Chuan, ofrecen contribuciones importantes en la atención de portadores de transtornos mentales en Centros de Atención Psicosocial (CAPS), y, la Danza de Vientre, con sus características, reune condiciones para ofrecer contribución terapéutica, particularmente, para las mujeres usuárias de estos Centros. De esta forma, el presente estudio tuvo como objetivo verificar la contribución de la Danza de Vientre en la educación corporal, salud física e mental de las mencionadas mujeres. Para esto, planeamos once aulas de Danza de Vientre que desarrollamos semanalmente con nueve mujeres, con diferentes diagnósticos, usuárias de un CAPS, que se contituyeron en los sujetos del estudio. A través de sus declaraciones, obtenidas de la aplicación de un cuestionário antes de haber participado de las aulas y después de finalizada la experiencia; así como, de las declaraciones dadas al final de cada aula, que fueron registradas por dos observadores participantes, entrenados para ese fin, pudimos verificar la contribución de las actividades realizadas. Los resultados mostraron que la Danza de Vientre, contribuyó en la mejoria de la auto-estima y de la autoconfianza de las mujeres, auxiliando su tratamiento en el CAPS, verificamos considerables beneficios en la educación corporal y en su salud física y mental, mejorando su calidad de vida $\mathrm{y}$, consecuentemente, permitiendo una mejor convivencia em su ambiente social y familiar.

Términos-clave: danza de vientre, salud, educación. 